\title{
INFORMATION SYSTEMS FACULTY PERCEPTIONS OF ETHICAL WORK CLIMATE AND JOB SATISFACTION
}

\author{
Kevin S. Floyd \\ Middle Georgia State College \\ kevin.floyd@maconstate.edu
}

\author{
Johnathan M. Yerby \\ Middle Georgia State College \\ johnathan.yerby@maconstate.edu
}

\begin{abstract}
The purpose of this research was to provide an overview of the current research literature in the areas of ethical work climate and employee job satisfaction, and then present a model that will help guide future research on the relationship among egoistic ethical work climate, benevolent ethical work climate, and principled ethical work climate and job satisfaction as perceived by information systems faculty at institutions of higher education in the southeastern United States. The study determined which ethical work climates were significantly positively and negatively correlated to job satisfaction of individuals employed in higher education. The analysis demonstrated a foundation for higher education institutions to choose to implement a particular ethical work climate to increase job satisfaction. The paper concluded with implications for future research.
\end{abstract}

\section{Keywords}

Ethical Work Climate, Job Satisfaction, Information Systems Faculty, Higher Education

\section{INTRODUCTION}

In recent years, institutions of higher education have been faced with profound changes and challenges. In the current economic climate, extensive budget cuts have become commonplace resulting in little to no money for faculty pay raises. At the same time, increased faculty workload, larger classroom size, and increased accountability have become common place (Wilson, 2011). Lake (2011) reported an increase in faculty workload amid budget cuts. A recent Inside Higher Ed. article (Kiley, 2013) cited efforts to increase graduation rates, performance-funding policies, and alignment with state goals as top issues for academe. Given the changing work climate at higher education institutions, a major concern for higher education leaders is to ensure continued faculty job satisfaction.

In a study conducted by Gormley (2010), the organizational work climate can have a significant impact on organization performance and job satisfaction. Additionally, ethical work climate has been found to influence employee job satisfaction (Parker et al. 2003). A challenge for higher education leaders is to create what Jose and Thibodeaux (1999) referred to as an "ethical fit," a fit between the institutions ethical strategy and its systems, structures, and culture in an effort to create an ethical organization work climate that helps foster faculty job satisfaction despite the ever growing and emerging challenges facing academe.

Ethical work climate plays a major role in shaping employee attitudes and organizational relationships. Therefore, understanding the relationship among the ethical work climate and job satisfaction is an important area of research. While previous studies have been published on job satisfaction and ethical work climate, the relationship between ethical work climate and job satisfaction in higher education, particularly among IS faculty is currently under researched. This study will attempt to bridge this gap by examining the causal relationships among ethical work climate and employee job satisfaction among IS faculty in higher education.

\section{THEORITICAL BACKGROUND}

\section{Ethical Work Climate}

In his seminal work on organizational climate, Schneider (1975) defined work climate as "psychologically meaningful molar descriptions that people can agree characterize a system's practices and procedures" (p. 474). According to Schneider and Rentsch (1988), climate is the way in which organizations define routine practices 
that are supported and rewarded by the organization. In most cases, an organization may consist of multiple work climates due to variances in its functions and processes (Schneider, 1975). A work climate may also vary as a result of differences among individual employees, work groups, and employees' positions (Victor \& Cullen, 1988).

Schneider (1983) defined the ethical aspects of work climate as the existence of a normative system as perceived by employees that enables them to respond to ethical or moral issues that occur in the work place. As a subset of the general organizational work climate, the ethical work climate construct reflects organizational practices with moral consequences. The ethical work climate develops when employees believe that certain forms of ethical behavior are expected standards and norms for decision making within the organization or department. Ethical work climates are not simply based on an individual's ethical standards or level of moral development. They instead represent components of the employees' work environment as perceived by its members (Cullen, Parboteeah, \& Victor, 2003). In addition, Payne (1990) described an ethical work climate as a social system that is composed of individuals who share a formal or informal structure such as a department, organization, or network. Schminke, Arnuad, and Kuenzi (2007) further explained that the ethical work climate includes the prevalent ethical values, norms, attitudes, feelings, and behaviors of the members (employees) that make up the social organization. Verbos et al. (2007) suggested that in organizations with a positive ethical climate, employees hold the view that "the right thing to do is the only thing to do" (p. 17).

In considering definitions of ethical work climate, it is also important to understand individual moral development. Kohlberg (1969) proposed the cognitive moral development (CMD) theory that explained that it is the individual who makes a determination of what is right or wrong. The CMD theory identifies three levels of moral development-the pre-conventional, conventional, and post-conventional levels. Each level is composed of two stages for a total of six stages. Individuals move forward though the stages by a step sequence, which follows an invariant path from one stage to the next. Individuals can only progress from a lower stage to the next higher stage and cannot derive moral reasoning from more than two adjacent stages at one time. Kohlberg (1969) explained that in the first two stages of cognitive development, the locus of concern is the individual; in the third and fourth stages the individual's referent group becomes a larger social system; and, in the highest stages consideration is given to humanity and other considerations as a whole. According to Kohlberg (1969), those individuals who fall into the first two stages of CMD are more likely to benefit from an ethical work climate based on rules and guidelines. On the other hand, individuals with a higher level of CMD are less likely to be affected by environmental cues and rely on their own moral development to help others deal with ethical issues within the organization (Kohlberg, 1969).

Cullen et al. (2003) defined three basic ethical standards associated with ethical work climates that parallel Kohlberg's (1969) stages of individual cognitive and moral development: egoistic (self-interest), benevolent (caring), and principled. The egoistic climate is characterized by employee self-interests. An employee makes decisions that promote personal gain, ignoring the needs or interests of others. Employees have less concern for others in the organization and the organization as a whole. Employees may feel that the organization does not conform to the appropriate ethical standards or societal expectations. On the other hand, benevolent climates encourage individuals to be concerned with the well-being of others both inside and outside of the organization. In a benevolent environment, an employee is likely to make decisions that seek to maximize joint interests even when it means lesser satisfaction of individual needs (Weber, 1995). In a principled or rule based climate, ethical decisions are made based on the interpretation of rules, laws, and standards in the normative expectations of the organization or social unit (Victor \& Cullen, 1988). Over the years, numerous articles (e.g., Clinard, 1983; Clinard \& Yeager, 1980; Cullen, Maakestad, \& Cavender, 1987; Victor \& Cullen, 1988; Weiss, 1983) have reported on the role that organizational climate plays on influencing employee ethical or unethical behaviors. 


\section{Job Satisfaction}

Smith, Kendall, \& Hulin (1975) defined job satisfaction as "the perceived characteristics of the job in relation to an individual's frames of reference" (p. 12). To further refine the definition, job satisfaction is the positive emotional state that results from the overall evaluation of an employee's job (Locke, 1976; Shaffer \& Harrison, 1998). The evaluation of job satisfaction can include facets such as an overall impression of one's job, the work one is expected to complete as part of his/her job, pay, opportunities for promotion, and an impression of one's supervision (Smith, 1985).

The effects of job satisfaction, including benefits to both the employee and the organization, have been welldocumented in the literature. An employee's intention to leave an organization is related to his/her job satisfaction (Abelson, 1987; Arnold \& Feldman, 1982; Baroudi, 1985; Sager \& Johnston, 1989; Sager, Varadarajan, \& Futrell, 1988). Further, employee evaluation criteria such as increased job performance, increased productivity, and decreased absenteeism are related to a higher level of an employee's job satisfaction (Brown \& Peterson, 1994; Seashore \& Taber, 1975; Singh, Verbeke, \& Rhoads, 1996; Vroom, 1964). With these desirable outcomes in mind, research has turned to investigating ways to positively impact an employee's job satisfaction. Outside of the standard factors related to benefits and monetary gain, the relationship between an ethical work climate and job satisfaction has been well-documented.

\section{Ethical Work Climate and Job Satisfaction}

Research (e.g., Bartels, Harrick, Martell, \& Strickland, 1998; Cohen, 1995; Malloy \& Agarwal, 2003) has shown a significant correlation between organizational work climate and employee productivity and job satisfaction. The work climate is a factor that can have a significant impact on the productivity and satisfaction of its employees (Malloy \& Agarwal, 2003). In addition, numerous studies have suggested that work climate can play a major role in influencing ethical conduct among groups and individuals (Ambrose, Arnaud, \& Schminke, 2008; Andreoli \& Lefkowitz, 2009; Cohen, 1995; Malloy \& Agarwal, 2003; Scheider, 1975; Victor \& Cullen, 1988).

As there are several antecedents that lead to job satisfaction, this study focused specifically on the type of ethical work climate and how it affects job satisfaction. In a study of 1,174 working adults, Elci and Alpkan (2009) discovered a significant positive relationship between the egoistic work climate and low levels of work satisfaction. The study specifically showed that a self-interest climate type proved to have a negative influence on job satisfaction, whereas team interest, social responsibility, and principled climates positively impacts work satisfaction.

In an egoistic climate decisions are made to benefit the individual's interest, company, social, or economical interest. Research (Woodbine, 2006; Joseph \& Deshpande, 1997), has concluded that an egoistic work climate is a strong predictor of job dissatisfaction.

The benevolent work climate focuses on the interests of a social group as a whole. In a benevolent work climate, decisions are aimed to coincide with socially responsible behavior. Deshpande (1996) discovered a higher level of job satisfaction in organizations that fostered a benevolent or caring work climate.

A principled work climate proposes that decisions are made in accordance with the established rules and codes. Deshpande (1996) concludes that in a principled climate law and professional codes lead to a positive overall satisfaction. However, the study fails to support a significant finding when exploring personal morality, which is one of the dimensions of the principled work climate.

Several studies have demonstrated that dimensions of ethical climate lead to more satisfied employees ( Babin, Boles, \& Robin, 2000; Deshpande, 1996; Herndon et al., 1999; Jaramillo, Prakash, \& Solomon, 2006; Joseph \& Deshpande, 1997; Koh \& Boo, 2001; Martin \& Cullen, 2006; Mulki, Jaramillo, \& Locander, 2006; Schneider \& Snyder, 1975; Schwepker, 2001; Schwepker \& Hartline, 2005; Sims \& Keon, 1997; Ulrich, O’Donnell, Taylor, Farrar, Danis, \& Grady, 2007). Subsequently, a conflict between an employee's personal ethics and the 
perceptions of top manager's ethical values has been found to increase stress and reduce job satisfaction. A significant positive relationship exists when there is a caring or benevolent ethical work climate (Ambrose, Arnaud, \& Schminke, 2008). Deshpande (1996) found that climate types did not significantly influence satisfaction with pay, but did influence employee's satisfaction with other job facets such as, promotions, supervisors, work, and the overall job. Employees within an organization that exhibited a caring work climate were significantly more satisfied.

While much has been written about corporate ethical work climate and their impact on job satisfaction in the business organization, the search for comparable literature in higher education has been unsuccessful. Since little, if any, research currently exists, further analysis is needed to investigate the role of ethical work climate and job satisfaction in higher education. Based on previous research findings (Babin, Boles, \& Robin, 2000; Deshpande, 1996; Herndon et al., 1999; Jaramillo, Prakash, \& Solomon, 2006; Joseph \& Deshpande, 1997; Koh \& Boo, 2001; Martin \& Cullen, 2006; Mulki, Jaramillo, \& Locander, 2006; Schwepker, 2001; Schwepker \& Hartline, 2005; Sims \& Keon, 1997; Ulrich, O’Donnell, Taylor, Farrar, Danis, \& Grady, 2007) , a research model was hypothesized (see Fig. 1) and the following hypotheses were examined:

$\mathrm{H}_{1}$ : Benevolent ethical work climate has a positive effect on IS faculty job satisfaction

$\mathrm{H}_{2}$ : Egoistic ethical work climate has a negative effect on IS faculty job satisfaction.

$\mathrm{H}_{3}$ : Principled ethical work climate has a positive effect on IS faculty job satisfaction

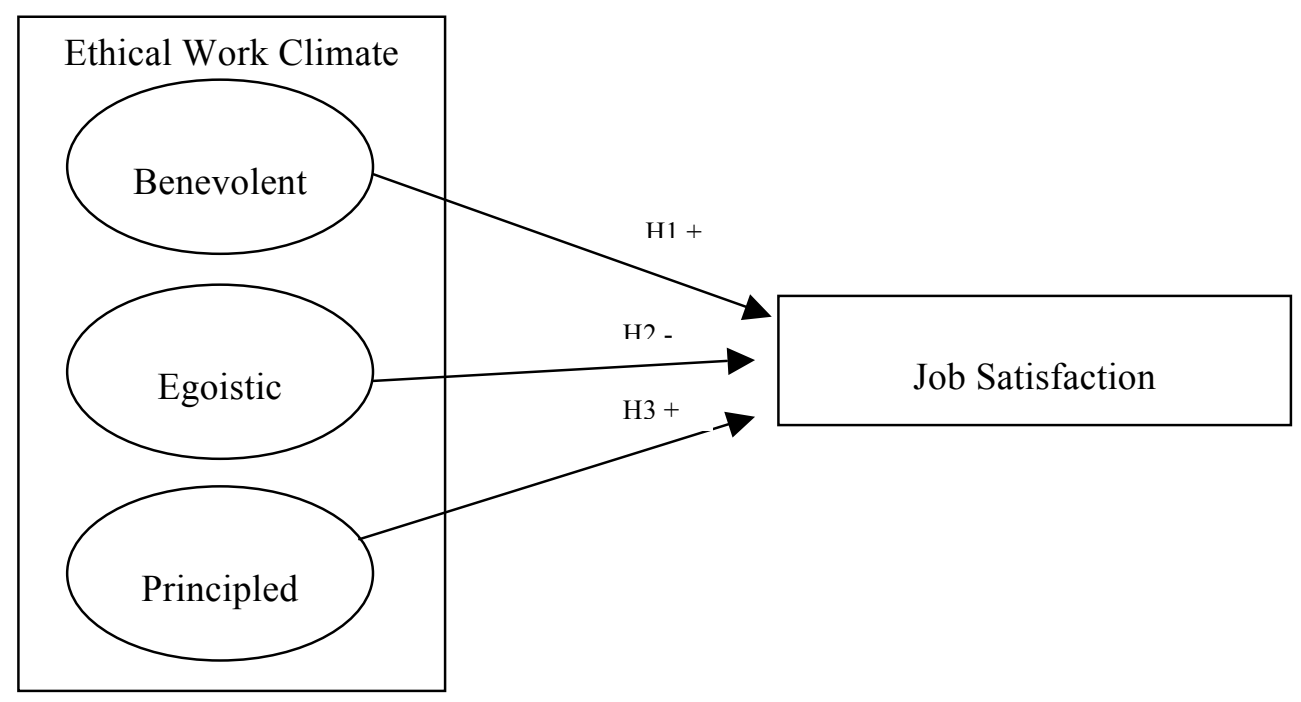

Figure 1: Ethical Work Climate and Job Satisfaction Hypothesized Model

\section{METHODOLOGY}

This study uses the Abridged Job Descriptive Index/Job In General (aJDI/JIG) scale (Ironson, Smith, Brannick, Gibson \& Paul, 1989) and the Ethical Work Climate questionnaire used to measure ethical work climate by Victor and Cullen (1987). Participants include IS faculty from institutions of higher education in the Southeastern United States. Results are analyzed using Statistical Package for Social Sciences (SPSS) and Smart PLS (Ringle, Wende, Will, 2005). 


\section{Instrumentation}

The instrumentation (see appendix) for this study consisted of 54 questions, categorized as follows: sixteen (16) items from the Ethical Work Climate questionnaire used to measure ethical work climate by Victor and Cullen (1987), and 38 items from the Abridged Job Descriptive Index/Job In General (aJDI/JIG) scale (Ironson, Smith, Brannick, Gibson \& Paul, 1989). The aJDI/JIG scale is a global scale and measures six facets of job satisfaction: people on your present job, job in general, work on present job, pay, opportunities for promotion, and supervision.

For purposes of this study, the top five-loading questions on the EWC questionnaire (Victor \& Cullen, 1987) from the ethical dimensions [benevolence (B), and egoistic (E)] and the top six-loading questions from the dimension [principle (P)] were used used to develop the ethical work climate component of the research questionnaire since these dimensions parallel Kohlberg's (1969) stages of individual cognitive and moral development. This includes questions 1-5 (benevolence), questions 8, 10,11, 14, 15, and 29 (principle), and questions 16-19, and 21 (egoistic). This combination of questions includes all of the ethical work climate factors defined by Victor and Cullen (1987).

\section{Participants}

The participants for this study included currently employed, full time, and tenure-track information systems faculty from 136 institutions of higher education in the Southeastern United States. These institutions were classified as teaching institutions. The work environment assumes a normal faculty workload of teaching four courses per semester, appropriate scholarly activity, and performance of service to the institution and the community.

Using the National Center for Education Statistics School Search Engine (nces.ed.gov), a total of 136 public institutions of higher education in the Southeastern United States, which offered at least a four-year program in computer science, information technology, information systems, or information sciences were found. Southeastern states were defined as Alabama, Arkansas, Florida, Georgia, Kentucky, Louisiana, Mississippi, North Carolina, South Carolina, Tennessee, Virginia, and West Virginia. From the total 136 institutions, 85 institutions were randomly selected.

Over 1,200 e-mail addresses were collected from the 85 randomly selected institution's online faculty directories. From the collected e-mail addresses up to 10 e-mail addresses were randomly selected from each institution to ensure the sample was fairly representative. This resulted in a total of 700 since not all institutions had 10 faculty in there IS department. Out of the 700 surveys distributed, 99 were received while 15 were incomplete. Therefore the total number of usable questionnaires in this study was 82 with a response rate of $12 \%$. Hair et al. (2009) stated that the appropriate minimum sample size for a research is to have 15 observations for each independent variable. As there are 3 independent variables measuring ethical work climate in this study, a minimum sample size of 45 is needed. Since there were a total of 82 respondents in this study, the sample size for the research is adequate.

Of the total sample, $31.7 \%$ were female $(\mathrm{N}=26)$ and $61 \%$ were male $(\mathrm{N}=50)$. Six respondents did not report their gender. The median age range for respondents was $45-49$ years. The majority of respondents (76.8\%) indicated that their institution offered some type of graduate level degree.

\section{Procedures}

The survey was administered electronically using Survey MonkeyC). The participants were guaranteed confidentiality of responses and assured that their responses could not be used to identify them.

The results of the surveys were coded and entered into the Statistical Package for Social Sciences (SPSS) to obtain descriptive statistics, determine validity of the measures, and determine if statistically significant correlations exist between the variables under study. Correlations between all variables were computed using the Spearman $\mathrm{r}$ since the distribution of scores were in ordinal form (Salkind, 2008; Sprinthall, 2003). Smart PLS (Ringle, Wende, Will, 2005) was used for structured equation modeling (SEM). SEM was used for data analysis 
because it is an effective statistical approach for confirming relationships and revealing their causal nature and strength (Bollen, 1989; Bollen \& Long, 1993).

A factor analysis with varimax rotation was performed on the ethical work climate questions. The factors of benevolent ethical work climate, principled ethical work climate, and egoistic ethical work climate resulted as expected. One of the ethical work climate questions (\#46) loaded into a separate, fourth factor. As a result, it was dropped from the analysis. All questions from the Job Satisfaction survey were used since the research focuses on job satisfaction in general. Using data from the sample of 82 faculty who completed the instrument, Cronbach's alpha (Table 1) was calculated for benevolent ethical work climate $(\alpha=.883)$, principled ethical work climate $(\alpha=.797)$, egoistic ethical work climate $(\alpha=763)$, and job satisfaction $(\alpha=.916)$. As these numbers reveal, there was an excellent degree of internal consistency in the responses to each set of items.

Scales for benevolent ethical work climate, principled ethical work climate, egoistic ethical work climate, and job satisfaction were formed by averaging responses on the Likert scales for each respondent on the respective items for each construct.

\section{Results}

The descriptive statistics for, and the correlation between, benevolent ethical work climate, principled ethical work climate, egoistic ethical work climate, and job satisfaction are presented in Table 1. Statistical analysis reveals that there is a negative and significant correlation $(\mathrm{r}=-.542 ; \mathrm{p}<.001)$ between the egoistic EWC and job satisfaction (supporting H1). A positive and significant correlation at the $(r=.381 ; p<.001)$ exists between the benevolent ethical work climate and job satisfaction (supporting H2). However, the results did not find a significant correlation $(\mathrm{r}=.080 ; \mathrm{p}=.292)$ between the principled EWC and faculty job satisfaction, which meant that hypothesis 3 was rejected.

\begin{tabular}{llccc}
\hline & BEWC & EEWC & PEWC & JS \\
\hline 1. Benevolent & EWC & - & & \\
2. Egoistic EWC & $-.456^{* *}$ & -- & & \\
3. Principled EWC & $.654^{* *}$ & $-.327^{* *}$ & -- & -- \\
4. Job Satisfaction & $.381^{* *}$ & $-.542^{* *}$ & .080 & 2.11 \\
\hline Mean & 3.10 & 2.52 & 3.85 & .59 \\
Standard Dev. & .92 & .72 & .79 & 0,3 \\
Scale Min/Max & 1 to 5 & 1 to 5 & 1 to 5 & .916 \\
Cronbach's $\alpha$ & .883 & .763 & .797 & \\
$* * p<.001$ & & & & \\
\hline
\end{tabular}

\section{Table 1: Spearman Correlations and Descriptive Statistics}

To further distinguish the contribution of ethical work climate on job satisfaction, a path model was performed using SmartPLS (partial least squares) with EWC as the latent variables and job satisfaction as the dependent variable. The path analysis shows that $71.8 \%$ of the variance in job satisfaction can be explained by the perceived EWC of the organization.

The hypothesized structural model was tested using Smart PLS. As shown in table 2, the results suggested that model fits well with the data. Figure 2 presents the standardized path coefficients and significance of the relationships of the variables in the model. The first hypothesis on the impact of benevolent ethical work climate on job satisfaction was supported $(\beta=0.381 ; \mathrm{t}=5.620 ; \mathrm{p}=0.000)$. According to hypothesis two, the egoistic ethical work climate had an indirect effect on job satisfaction $(\beta=-0.542 ; \mathrm{t}=10.577 ; \mathrm{p}=0.000)$. Lastly, the principled ethical work climate had no impact on faculty job satisfaction $(\beta=0.080 ; \mathrm{t}=1.055 ; \mathrm{p}=0.292)$. 


\begin{tabular}{ccccccc}
\hline & $\begin{array}{c}\text { Relationship of } \\
\text { variables }\end{array}$ & $\beta$ & Sample Mean & $\begin{array}{c}\text { Standard } \\
\text { Deviation }\end{array}$ & t-statistic & p-value \\
\hline H1 & BEWC -> JS & 0.381 & 0.375 & 0.068 & 5.620 & $0.000^{* *}$ \\
H2 & EEWC -> JS & -0.542 & -0.548 & 0.051 & 10.577 & $0.000^{* *}$ \\
H3 & PEWC -> JS & 0.080 & 0.085 & 0.076 & 1.055 & 0.292 \\
$* * p<0.01$ & & & & & & \\
\hline
\end{tabular}

Table 2: Parameter Estimates of the Structured Equation Model

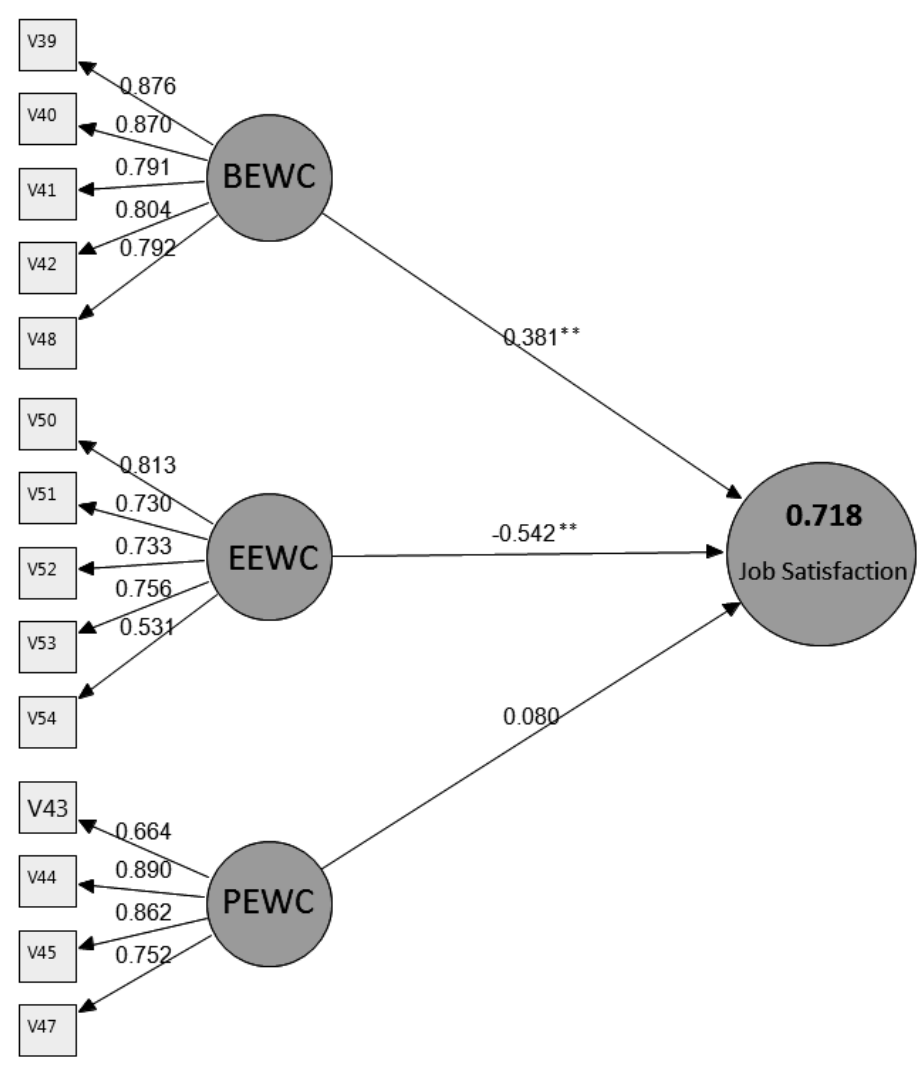

Figure 2: The Structured Equation Model

\section{DISCUSSION AND IMPLICATIONS}

The purpose of this research was to provide an overview of the current research literature in the areas of ethical work climate and employee job satisfaction, and then present a model that will help guide future research on the relationship among egoistic ethical work climate, benevolent ethical work climate, and principled ethical work climate and job satisfaction as perceived by information systems faculty at institutions of higher education in the southeastern United States. Currently, there is little if any, research on job satisfaction and ethical work climate in higher education. The results of this study will hopefully contribute to the literature on job satisfaction and ethical work climate, particularly in the area of higher education. The research could also be used as a framework to measure the effects of the ethical work climate in relation to job satisfaction of non-IS higher education faculty 
members in the Southeastern United States. Additionally, based on the results of the study, there is the opportunity to continue to refine and strengthen the EWC and Job Satisfaction instrument.

This study hypothesized that the benevolent and principled ethical work climate had a positive effect and egoistic ethical work climate has a negative effect on job satisfaction among IS faculty. One of the most significant findings is the strong indirect effect of the egoistic ethical work climate on job satisfaction. This is consistent with previous studies that report egoism or egotistic ethical work climate within the organization and a negative impact on job satisfaction (Woodbine, 2006; Deshpande, 1996). This suggests that faculty who agree that their work climate is focused on individual's interests, and company, social, or economic interests, tend to disagree that they are satisfied with their jobs.

On the other hand benevolent ethical work climate had a positive effect on job satisfaction. This finding suggests that when faculty perceives the ethical work climate within their academic department to be based on socially responsible behavior, job satisfaction is high. This is consistent with findings by Upchurch and Ruhland (1995) and Deshpande (1996). Cullen et al. (2003) explained that through employee empowerment, managers can bolster employees' sense of personal responsibility for individual decision and promote the development of a benevolent ethical work climate and in turn discourage the introduction of an egoistic ethical work climate and consequently reduce the incidence of ethical crises. The development of a benevolent ethical work climate may also significantly reduce self-centered interests and concerns that are typical in an egoistic ethical work climate. Cullen et al. (2003) suggested that in a benevolent ethical work climate, employees are more likely to take the benefit of the entire organization into consideration.

Third, there was no significant correlation between principled ethical work climate and job satisfaction, principled ethical. This suggests that the development of a benevolent ethical work climate that promotes team interest, esprit de corps, communication, and social responsibility will likely empower employees and raise the level of IS faculty job satisfaction more so than a principled ethical work climate based on codes of conduct, ethics training programs, rules, ethics policies, and compliance with professional standards. This finding is consistent with previous research reporting mixed results on the effectiveness of codes of ethics with only $35 \%$ of studies indicating that codes are effective in determining unethical behavior (Kaptein \& Schwartz, 2007). Codes of ethics are only effective in deterring unethical behavior if leadership is willing to enforce the rules and take appropriate action against employees' who violate it (Chonko \& Hunt, 1985; Trevino, 1992).

Another important implication of this study is that job satisfaction among faculty contributes to positive outcomes for students (Hagedorn, 2000). This may provide further incentive for leadership within IS academic departments to work to foster more benevolent ethical work climates.

Overall, the results reported in this study provide important information to the role that an ethical work climate, particularly a benevolent ethical work climate, plays faculty job satisfaction. Leadership can foster a benevolent climate by encouraging team interest or faculty working together for the overall benefit of the department. This could include faculty collaboration in the areas of research and service. Faculty development programs that emphasize benevolent reasoning and seek faculty input may also help to ensure a caring and productive academic environment. A key factor is the effort of leadership to keep faculty involved in the decision making process and seeking faculty input for continuous improvement. An environment where leadership emphasizes the ideals of professionalism, team work, and mentoring will ultimately have a greater impact than those that rely on codes of ethics or organizational guidelines as a means of promoting an ethical climate conducive to job satisfaction.

\section{LIMITATIONS AND FUTURE RESEARCH}

This study was restricted by the following limitations. First, causality cannot be confirmed since the research design was cross-sectional in nature. The effect of temporality can be examined in longitudinal studies. Secondly, this study attempted to measure perceptions of the ethical work climate by faculty in higher education. When participants are asked ethical questions it is possible that the respondents may attempt to answer the ethics related questions as they deem to be socially or culturally acceptable. 
In addition, the sample for this study was limited to faculty at institutions of higher education that teach a technology related discipline within the Southeastern United States. Future works on ethical work climate and job satisfaction can include institutions from other regions of the United States to further validate the outcomes of this study. This research can be used as a framework to measure the effects of the ethical work climate in relation to job satisfaction of non-IS higher education faculty members in the Southeastern United States or of IS faculty outside of the Southeastern United States. Additionally, based on the results of the study, there is the opportunity to continue to refine and strengthen the EWC and Job Satisfaction instrument.

Third, the ethical work climate fostered in an institution is not the single factor that correlates with overall job satisfaction. The ethical work climate affects job satisfaction in general as well as the vast number of factors that relate to differing levels of satisfaction for individuals. Future studies could attempt to differentiate individual ethics, organizational ethics, and ethical intention (Elango, Paul, Kundu \& Paudel, 2010). This study did not explicitly study personal versus organizational ethics.

Additionally, while this study did not focus directly on the relationship between principled and benevolent ethical work climate, it is worth noting the significant and positive relationship between the two constructs $(\mathrm{r}=.628$; $\mathrm{p}<.001)$. The strong correlation suggests that almost $40 \%$ of the variance in benevolent is related to principled ethical work climate. This may be an indication that principled work climate leads to a benevolent ethical work climate or vice-versa. Future research is needed to future explore this relationship.

Finally, it appears that leadership plays an active role in the development of an ethical work climate and a climate that ultimately leads to job satisfaction. Future research should be conducted to explore whether certain types of leadership are more conducive to the development of and ethical work climate.

\section{CONCLUSION}

In previous empirical studies, positive correlations were noted between the levels of job satisfaction in organization, and the levels of productivity and efficiency. Employers should seek to increase job satisfaction to improve the operations of the organization. This study specifically focused on information systems faculty from institutions of higher education in the Southeastern United States. Faculty members that experience higher levels of job satisfaction are more likely to have low levels of absenteeism, higher involvement in their responsibilities as a faculty member, and increased performance.

One of the antecedents of job satisfaction is the ethical work climate. This study theorizes that there are three general ethical work climates; egoistic, benevolent, and principled. The study also hypothesized that there is a negative correlation between the egoistic work climate and job satisfaction and there is a positive correlation between the principled and benevolent work climate, and job satisfaction. The hypotheses were tested by using a 34 question survey. The results indicate no relationship between principled ethical work climate and job satisfaction, a significant and positive relationship between benevolent ethical work climate and job satisfaction, and a significant and negative relationship between egoistic ethical work climate and job satisfaction. 


\section{REFERENCES}

1. Abelson, M. A. (1987). Examination of avoidable and unavoidable turnover. Journal of Applied Psychology, $72(3), 382-386$.

http://dx.doi.org/10.1037/0021-9010.72.3.382

2. Ambrose, M., Arnaud, A., \& Schminke, M. (2008). Individual Moral Development and Ethical Climate: The Influence of Person-Organization Fit on Job Attitudes. Journal of Business Ethics, 77(3), 323-333.

http://dx.doi.org/10.1007/s10551-007-9352-1

3. Andreoli, N., \& Lefkowitz, J. (2009). Individual and Organizational Antecedents of Misconduct in Organizations. Journal of Business Ethics, 85(3), 309-332.

http://dx.doi.org/10.1007/s10551-008-9772-6

4. Arnold, H. J. \& Feldman, D. C. A. (1982). Multivariate analysis of the determinants of job turnover. Journal of Applied Psychology, 67(3), 350-360. http://dx.doi.org/10.1037/0021-9010.67.3.350

5. Babin, B. J., Boles, J. S., \& Robin, D. P. (2000). Representing the perceived ethical work climate among marketing employees. Journal of the Academy of Marketing Science, 28, 345-358. http://dx.doi.org/10.1177/0092070300283004

6. Baroudi, J. J. (1985). The impact of role variables on is personnel work attitudes and intentions. MIS Quarterly, 9(4), 341-356.

http://dx.doi.org/10.2307/249234

7. Bartels, K. K., Harrick, E., Martell, K., \& Strickland, D. (1998). The Relationship between Ethical Climate and Ethical Problems within Human Resource Management. Journal of Business Ethics, 17(7), 799-804. http://dx.doi.org/10.1023/A:1005817401688

8. Bollen, K.A. (1989). Structural equations with latent variables. New York: Wiley.

9. Bollen, K.A., \& Long, J.S. (1993). Testing structural equation models. Thousand Oaks, CA: Sage Publications.

10. Brown, S. P. \& Peterson, R.A. (1994). The effect on sales performance and job satisfaction. Journal of Marketing, 58, 70-80. http://dx.doi.org/10.2307/1252270

11. Chonko, L.B., Hunt, S.D. (1985). Ethics and marketing management: An empirical investigation. Journal of Business Research, 13, 339-359. http://dx.doi.org/10.1016/0148-2963(85)90006-2

12. Clinard, M. B., \& Yeager, P. C. (1980). Corporate crime. New York: Free Press.

13. Clinard, M. B. (1983). Corporate ethics and crime. Beverly Hills, CA: Sage.

14. Cohen, D. V. (1995). Creating ethical work climates: A socioeconomic perspective. Journal of SocioEconomics, 24(2), 317-343. http://dx.doi.org/10.1016/1053-5357(95)90024-1

15. Cullen, F. T., Maakestad, W. J., \& Cavender, G. (1987). Corporate crime under attack. Cincinnati: Anderson.

16. Cullen, J. B., Parboteeah, K. P., \& Victor, B. (2003). The effects of ethical climates on organizational commitment: A two-study analysis. Journal of Business Ethics, 46, 127-141.

http://dx.doi.org/10.1023/A:1025089819456

17. Deshpande, S. P. (1996). The impact of ethical climate types on facets of job satisfaction: An empirical investigation. Journal of Business Ethics, 15(6), 655-660.

http://dx.doi.org/10.1007/BF00411800 
18. Elango, B., Paul, K., Kundu, S. K., \& Paudel, S. K. (2010). Organizational ethics, individual ethics, and ethical intentions in international decision-making. Journal of Business Ethics, 97(4), 543-561. http://dx.doi.org/10.1007/s10551-010-0524-z

19. Elçi, M., \& Alpkan, L. (2008). The impact of perceived organizational ethical climate on work satisfaction. Journal of Business Ethics, 84(3), 297-311. http://dx.doi.org/10.1007/s10551-008-9709-0

20. Gormley, D.K. (2010). Influence of work role and perceptions of climate on faculty organizational commitment. Journal of Professional Nursing, 26(2), 108-115. http://dx.doi.org/10.1016/j.profnurs.2009.11.001

21. Hagedorn, L.S. (2000). Conceptualizing faculty job satisfaction: Components, theories, and outcomes. New Directions for Institutional Research, 105, 5-20. http://dx.doi.org/10.1002/ir.10501

22. Hair, J.F., Black, W.C., Babin, B.J., \& Anderson, R.E. (2009). Multivariate Data Analysis. Upper Saddle River: Prentice Hall.

23. Herndon, N. C., Jr., Ferrell, O. C., LeClair, D. Y., \& Ferrell, L. K. (1999). Relationship of individual moral values and perceived ethical climate to satisfaction, commitment, and turnover in a sales organization. Research in Marketing, 15, 25-48.

24. Ironson, G. H., Smith, P. C., Brannick, M. T., Gibson, W. M. \& Paul, K. B. (1989). Construction of a job in general scale: A comparison of global, composite and specific measures. Journal of Applied Psychology, 74, $1-8$. http://dx.doi.org/10.1037/0021-9010.74.2.193

25. Jaramillo, F., Mulki, J. P., \& Solomon, P. (2006). The role of ethical climate on salesperson's role, stress, job attitudes, turnover intention, and job performance. Journal of Personal Selling \& Sales Management, 26, 271282. http://dx.doi.org/10.2753/PSS0885-3134260302

26. Joseph, J., \& Deshpande, S. P. (1997). The impact of ethical climate on job satisfaction of nurses. Health Care Management Review, 22, 76-83. http://dx.doi.org/10.1097/00004010-199701000-00010

27. Jose, A., \& Thibodeaux, M. S. (1999). Institutionalization of ethics: The perspective of managers. Journal of Business Ethics, 22, 133-143.

http://dx.doi.org/10.1023/A:1006027423495

28. Kaptein, M, \& Schwartz, M.S. (2007). The effectiveness of business codes: A critical examination of existing studies and the development of an integrated model. Journal of Business Ethics, 78, 111-127.

http://dx.doi.org/10.1007/s10551-006-9305-0

29. Kiley, K. (2013). State higher ed. group: Budget cuts no longer top issue. Inside Higher Ed. Retrieved July 18, 2013 from http://www.insidehighered.com/quicktakes/2013/01/09/state-higher-ed-group-budget-cuts-nolonger-top-issue

30. Koh, H. C., \& Boo, E. H. Y. (2001). The link between organizational ethics and job satisfaction: A study of managers in Singapore. Journal of Business Ethics, 29(4), 309-324. http://dx.doi.org/10.1023/A:1010741519818

31. Kohlberg, L. (1969). Stage and sequence: The cognitive-developmental approach to socialization, in D. A. Goslin (Ed.). Handbook of Socialization Theory and Research. Chicago: Rand McNally.

32. Lake, R. (2011). Workload has picked up, faculty at UNLV say. Las Vegas Review Journal. Retrieved July 15, 2013 from http://www.reviewjournal.com/news/education/workload-has-picked-faculty-unlv-say.

33. Locke, E. A. (1976). The nature and causes of job satisfaction. In. M. D. Dunnette (ed.). Handbook of industrial and organizational psychology (pp. 1297-1349). Chicago: Rand McNally. 
34. Malloy, D. C., \& Agarwal, J. (2003). Factors influencing ethical climate in a nonprofit organisation: an empirical investigation. International Journal of Nonprofit and Voluntary Sector Marketing, 8(3), 224-250. http://dx.doi.org/10.1002/nvsm.215

35. Martin, K., \& Cullen, J. (2006). Continuities and extensions of ethical climate theory: A meta-analytic review. Journal of Business Ethics, 69(2), 175-194. http://dx.doi.org/10.1007/s10551-006-9084-7

36. Mulki, J., Jaramillo, J., \& Locander, W. (2008). Effect of ethical climate on turnover intention: Linking attitudinal- and stress theory. Journal of Business Ethics, 78(4), 559-574. http://dx.doi.org/10.1007/s10551-007-9368-6

37. Mulki, J. P., Jaramillo, F., \& Locander, W. B. (2006). Effects of ethical climate and supervisory trust on salesperson's job attitudes and intentions to quit. Journal of Personal Selling \& Sales Management, 26(1), 1926. http://dx.doi.org/10.2753/PSS0885-3134260102

38. Parker, P. P., Baltes, B.B., Young, S.A., Huff, J.W., Altman, RA, Larnst, HA (2003). Relationships between psychological climate perceptions and work outcomes: A meta-analytic review. Journal of Organizational Behavior, 24, 389-416. http://dx.doi.org/10.1002/job.198

39. Payne, R. L. (1990). Method in our madness: A reply to jackofsky and Slocum. Journal of Organizational Behavior, 11, 77-80. http://dx.doi.org/10.1002/job.4030110110

40. Ringle, C.M., Wende, S., \& Will A. (2005). SmartPLS 2.0 (beta). Retrieved from http://www.smartpls.de.

41. Salkind, N.J. (2008). Statistics for people who think they hate statistics. Thousand Oaks, CA: Sage Publications.

42. Sager, J. K. \& Johnston, M. W. (1989). Antecedents and outcomes of organisational commitment: A study of salespeople. Journal of Personal Selling and Sales Management 9(4), 30-41.

43. Sager, J. K., Varadarajan, P. R., \& Futrell, C. M. (1988). Understanding salesperson turnover: A partial evaluation of Mobley's turnover process model. Journal of Personal Selling and Sales Management, 8(4), 20-35.

44. Schminke, M., Arnaud, A., \& Kuenzi, M. (2007). The power of ethical work climates. Organizational Dynamics, 36(2), 171-186.

http://dx.doi.org/10.1016/j.orgdyn.2007.03.005

45. Schneider, B., \& Rentsch, J. (1988). Managing climates and cultures: A future perspective. In J. Hage (Ed.), The future of organization (pp.181-200). Lexington, MA: Lexington Books.

46. Schneider, B. (1975). Organizational climate: An essay. Personnel Psychology, 28(4), 447-479. http://dx.doi.org/10.1111/j.1744-6570.1975.tb01386.x

47. Schneider, B., \& Synder, R.A. (1975). Some relationships between job satisfaction and organizational climate. Journal of Applied Psychology, 60(3), 313-328. http://dx.doi.org/10.1037/h0076756

48. Schneider, B. (1983). Work climates: An interactionist perspective. In N.W. Feimer and E. S. Geller (Eds.), Environmental Psychology: Directions and Perspectives (pp. 106-128). New York: Praeger.

49. Schwepker, C.H. (2001). Ethical climate's relationship to job satisfaction, organizational commitment, and turnover intention in the sales force. Journal of Business Research, 54(1), 39-52. http://dx.doi.org/10.1016/S0148-2963(00)00125-9

50. Schwepker, C. H., \& Hartline, M. D. (2005). Managing the ethical climate of customer-contact service employees. Journal of Service Research, 7(4), 377-397.

http://dx.doi.org/10.1177/1094670504273966 
51. Seashore, S. E. \& Taber, T. D. (1975). Job satisfaction indicators and their correlates. American Behavior and Scientist, 18(3), 333. http://dx.doi.org/10.1177/000276427501800303

52. Shaffer, M. S. \& Harrison, D. A. (1998). Expatriate's psychological withdrawal from international assignments: Work, non-work, and family influences. Personnel Psychology, 51(1), 87-118. http://dx.doi.org/10.1111/j.1744-6570.1998.tb00717.x

53. Sims, R. L., \& Keon, T. L. (1997). Ethical work climate as a factor in the development of person-organization fit. Journal of Business Ethics, 16(11), 1095-1105. http://dx.doi.org/10.1023/A:1017914502117

54. Singh, J., Verbeke, W., \& Rhoads, G. K. (1996). Do organizational practices matter in role stress processes? A study of direct and moderating effects for marketing-oriented boundary spanners. Journal of Marketing, 60, 69-86. http://dx.doi.org/10.2307/1251842

55. Smith, P. C. (1985). Summary report on the Job-in-General scale of the JDI. Bowling Green, OH: Bowling Green University Department of Psychology.

56. Smith, P. C., Kendall, L. M., Hulin, C. L. (1975). The measurement of satisfaction in work and retirement. Chicago: Rand McNally.

57. Sprinthall, R.C. (2003). Basic Statistical Analysis. Boston: Allyn \& Bacon

58. Trevino, L.K. (1992). The social effects of punishment in organizations: A justice perspective. Academy of Management Review, 17(4), 647-676.

59. Ulrich, C., O'Donnell, P., Taylor, C., Farrar, A., Danis, M., \& Grady, C. (2007). Ethical climate, ethics stress, and the job satisfaction of nurses and social workers in the United States. Social Science \& Medicine, 65(8), 1708-1719. http://dx.doi.org/10.1016/j.socscimed.2007.05.050

60. Upchurch, R.S., \& Ruhland, S.K. (1995). An analysis of ethical work climate and leadership relationship in lodging operations. Journal of Travel Research, 34(2), 36-42. http://dx.doi.org/10.1177/004728759503400208

61. Verbos, A. K., Gerard, J. A., Forshey, P. R., Harding, C. S., \& Miller, J. S. (2007). The positive ethical organization: Enacting a living code of ethics and ethical organizational identity. Journal of Business Ethics, 76(1), 17-33. http://dx.doi.org/10.1007/s10551-006-9275-2

62. Victor, B., \& Cullen, J. B. (1987). A theory and measure of ethical climate in organizations. In W. C. Frederick (Ed.), Research in Corporate Social Performance and Policy (pp. 51-71). Greenwich, CT: JAI Press.

63. Victor, B., \& Cullen, J. B. (1988). The organizational bases of ethical work climates. Administrative Science Quarterly, 33(1), 101-125. http://dx.doi.org/10.2307/2392857

64. Vroom, V.H. (1964). Work and motivation. New York: Wiley.

65. Weber, J. (1995). Influences upon organizational ethical subclimates: A multi-departmental analysis of a single firm. Organizational Science, 6(5), 509-523.

http://dx.doi.org/10.1287/orsc.6.5.509

66. Weiss, W. L. (1983). Minerva's owl: Building a corporate value system. Journal of Business Ethics, 5, 243247.

http://dx.doi.org/10.1007/BF00383632

67. Wilson, R. (2011). Colleges are calling off the deals that allowed many professors time out from teaching. Chronicle of Higher Education. Retrieved July 1, 2013 from http://chronicle.com/article/Colleges-AreCalling/129429/. 
68. Woodbine, G.F. (2006). Ethical climate types and job satisfaction: Study of Chinese financial institutions. International Review of Business Papers 2(1), 86-99. 
APPENDIX

\section{Survey Instrument}

Job Satisfaction

Part I - Job Satisfaction - People on Your Present Job

1. Think of the majority of people with whom you work or meet in connection with your work. Does the following term describe the people at your job? "Boring"

Yes

No

Cannot Decide

2. Think of the majority of people with whom you work or meet in connection with your work. Does the following term describe the people at your job? "Slow"

Yes

No

Cannot Decide

3. Think of the majority of people with whom you work or meet in connection with your work. Does the following term describe the people at your job? "Responsible"

Yes

No

Cannot Decide

4. Think of the majority of people with whom you work or meet in connection with your work. Does the following term describe the people at your job? "Smart"

Yes

No

Cannot Decide

5. Think of the majority of people with whom you work or meet in connection with your work.

Does the following term describe the people at your job? "Lazy"

Yes

No

Cannot Decide

6. Think of the majority of people with whom you work or meet in connection with your work. Does the following term describe the people at your job? "Frustrating"

Yes

No

Cannot Decide 
Part II- Job Satisfaction - Job in General

7. Think of your job in general. All in all, does the following term describe what is it like most of the time? "Good"

Yes

No

Cannot Decide

8. Think of your job in general. All in all, does the following term describe what is it like most of the time? "Undesirable"

Yes

No

Cannot Decide

9. Think of your job in general. All in all, does the following term describe what is it like most of the time? "Better than most"

Yes

No

Cannot Decide

10. Think of your job in general. All in all, does the following term describe what is it like most of the time? "Disagreeable"

Yes

No

Cannot Decide

11. Think of your job in general. All in all, does the following term describe what is it like most of the time?

"Makes me content"

Yes

No

Cannot Decide

12. Think of your job in general. All in all, does the following term describe what is it like most of the time? "Excellent"

Yes

No

Cannot Decide

13. Think of your job in general. All in all, does the following term describe what is it like most of the time? "Enjoyable"

Yes

No 


\section{Cannot Decide}

14. Think of your job in general. All in all, does the following term describe what is it like most of the time? "Poor"

Yes

No

Cannot Decide

Part III - Job Satisfaction - Pay

15. Think of the pay you get now. Does the following phrase describe your present pay?

"Barely live on income"

Yes

No

Cannot Decide

16. Think of the pay you get now. Does the following phrase describe your present pay?

"Bad"

Yes

No

Cannot Decide

17. Think of the pay you get now. Does the following phrase describe your present pay?

"Well paid"

Yes

No

Cannot Decide

18. Think of the pay you get now. Does the following phrase describe your present pay? "Underpaid"

Yes

No

Cannot Decide

19. Think of the pay you get now. Does the following phrase describe your present pay? "Comfortable"

Yes

No

Cannot Decide

20. Think of the pay you get now. Does the following phrase describe your present pay?

"Enough to live on"

Yes

No 


\section{Cannot Decide}

Part IV - Job Satisfaction - Work on Present Job

21. Think of the work you do at present. Does the following term describe the work that your currently do? "Fascinating"

Yes

No

Cannot Decide

22. Think of the work you do at present. Does the following term describe the work that your currently do? "Satisfying"

Yes

No

Cannot Decide

23. Think of the work you do at present. Does the following term describe the work that your currently do? "Good"

Yes

No

Cannot Decide

24. Think of the work you do at present. Does the following term describe the work that your currently do? "Exciting"

Yes

No

Cannot Decide

25. Think of the work you do at present. Does the following term describe the work that your currently do? "Rewarding"

Yes

No

Cannot Decide

26. Think of the work you do at present. Does the following term describe the work that your currently do? "Uninteresting"

Yes

No

Cannot Decide

Part V - Job Satisfaction - Opportunities for Promotion 
27. Think of the opportunities for promotion that you have now. Does the following term or statement describe your opportunities for promotion? "Good opportunities for promotion"

Yes

No

Cannot Decide

28. Think of the opportunities for promotion that you have now. Does the following term or statement describe your opportunities for promotion? "Opportunities somewhat limited"

Yes

No

Cannot Decide

29. Think of the opportunities for promotion that you have now. Does the following term or statement describe your opportunities for promotion? "Dead-end job"

Yes

No

Cannot Decide

30. Think of the opportunities for promotion that you have now. Does the following term or statement describe your opportunities for promotion? "Good chance for promotion"

Yes

No

Cannot Decide

31. Think of the opportunities for promotion that you have now. Does the following term or statement describe your opportunities for promotion? "Fairly good chance of promotion"

Yes

No

Cannot Decide

32. Think of the opportunities for promotion that you have now. Does the following term or statement describe your opportunities for promotion?

"Regular promotions"

Yes

No

Cannot Decide

Part VI - Job Satisfaction - Supervision

33. Think of the kind of supervision that you get on your job now. Does the following term or statement describe your supervisor? "Praises good work"

Yes

No 


\section{Cannot Decide}

34. Think of the kind of supervision that you get on your job now. Does the following term or statement describe your supervisor? "Tactful"

Yes

No

Cannot Decide

35. Think of the kind of supervision that you get on your job now. Does the following term or statement describe your supervisor? "Influential"

Yes

No

Cannot Decide

36. Think of the kind of supervision that you get on your job now. Does the following term or statement describe your supervisor? "Up-to-date"

Yes

No

Cannot Decide

37. Think of the kind of supervision that you get on your job now. Does the following term or statement describe your supervisor? "Annoying"

Yes

No

Cannot Decide

38. Think of the kind of supervision that you get on your job now. Does the following term or statement describe your supervisor?

"Knows job well"

Yes

No

Cannot Decide

Ethical Work Climate

Judge how strongly each statement describes your immediate work environment.

39. What is best for everyone in my immediate work unit is the major consideration here

Strongly Disagree

Disagree

Neither Agree or Disagree

Agree

Strongly Agree

40. The most important concern is the good of all the people as a whole in my immediate 
work unit.

Strongly Disagree

Disagree

Neither Agree or Disagree

Agree

Strongly Agree

41. Our major concern is always what is best for the other person

Strongly Disagree

Disagree

Neither Agree or Disagree

Agree

Strongly Agree

42. In my immediate work unit, people look out for each other's good

Strongly Disagree

Disagree

Neither Agree or Disagree

Agree

Strongly Agree

43. In my immediate work unit, it is expected that you will always do what is right for the students and the public

Strongly Disagree

Disagree

Neither Agree or Disagree

Agree

Strongly Agree

44. People in my immediate work unit are expected to comply with the law and professional standards over and above other considerations

Strongly Disagree

Disagree

Neither Agree or Disagree

Agree

Strongly Agree

45. In my immediate work unit, people are expected to strictly follow legal or professional standards

Strongly Disagree

Disagree

Neither Agree or Disagree

Agree

Strongly Agree 
46. In my immediate work unit, the first consideration is whether a decision violates any law

Strongly Disagree

Disagree

Neither Agree or Disagree

Agree

Strongly Agree

47. Successful people in my immediate work unit go by the book

Strongly Disagree

Disagree

Neither Agree or Disagree

Agree

Strongly Agree

48. People in my immediate work unit strictly obey the institutional/school policies

Strongly Disagree

Disagree

Neither Agree or Disagree

Agree

Strongly Agree

49. In my immediate work unit, people protect their own interests above all else

\section{Strongly Disagree}

Disagree

Neither Agree or Disagree

Agree

Strongly Agree

50. In my immediate work unit, people are mostly out for themselves

Strongly Disagree

Disagree

Neither Agree or Disagree

Agree

Strongly Agree

51. There is no room for one's own personal morals or ethics in my immediate work unit

Strongly Disagree

Disagree

Neither Agree or Disagree

Agree

Strongly Agree

52. People in my immediate work unit are expected to do anything to further the work unit's interests, regardless of the consequences 
Strongly Disagree

Disagree

Neither Agree or Disagree

Agree

Strongly Agree

53. Work is considered substandard only when it hurts the immediate work unit's interests

Strongly Disagree

Disagree

Neither Agree or Disagree

Agree

Strongly Agree

54. Each person in my immediate work unit decides for themselves what is right and wrong

Strongly Disagree

Disagree

Neither Agree or Disagree

Agree

Strongly Agree

Demographics

55.Which of the following best describes the academic unit that you teach in?

\section{Computer Science \\ Information Systems \\ Information Technology \\ Other (please specify)}

56. Which of the following best describes your institution?

Doctorate-granting University

Master's Colleges and University

Baccalaureate College

Associate's College

What is your gender?

Female

Male

57. Which of the following best describes your age?

Below 25

25 - less than 30

30 - less than 35

35 - less than 40

40 - less than 45

45 - less than 50 
50 - less than 55

55 - less than 60

60 or above 